Radoslav Eraković*

Nevena Varnica

Filozofski fakultet

Univerzitet u Novom Sadu
UDK: 821.163.42-1.09 Marulić M. 821.163.42-141 Kovačević G. DOI: $10.19090 /$ gff.2021.1.205-217

Originalni naučni rad

\title{
LEPOTA, MAČ I MOLITVA: LIK STAROZAVETNE UDOVICE IZ VETULIJE U STVARALAŠTVU MARKA MARULIĆA I GAVRILA KOVAČEVIĆA
}

U ovom radu predstavljeni su rezultati uporedne analize poetsko-epskih ostvarenja Marka Marulića (1450-1524) i Gavrila Kovačevića (1765-1832), inspirisanih podvigom starozavetne junakinje Judite (Marulić 1521; Kovačević 1808). Posmatrano iz savremene književnoistorijske i kulturološke perspektive, način na koji je preoblikovana tematska struktura starozavetnog predloška u delima dvojice južnoslovenskih pesnika, potvrđuje ispravnost teorijske pretpostavke o uticaju drevnih mitova na stvaranje i oblikovanje nacionalno-imagotipskih sistema (Fischer, 2009). Naime, pseudofaktografsko stapanje prelomnih događaja iz istorija različitih carstava (vavilonskog, asirskog, pa čak i turskog) opravdalo je postupak hiperbolizacije vojne moći demonizovanih nevernika, koje je trijumfalno porazio malobrojni ali pobožni narod. U inicijalnoj fazi ovog istraživačkog poduhvata posebna pažnja bila je posvećena tumačenju intertekstualnih veza između popularne deuterokanonske pripovesti i spevova dvojice autora, čija dela nikada do sada nisu bila predmet komparativnog iščitavanja. Ovakav pristup književnoistorijskoj građi, omogućio je preciznije identifikovanje nedovoljno proučenih žanrovskih, poetičkih i tematskih linija dodira između reprezentativnih segmenata stvaralačkog opusa renesansnog i predromantičarskog pesnika.

Ključne reči: Marko Marulić, Gavrilo Kovačević, Knjiga o Juditi, religiozni epovi, južnoslovenske književnosti, renesansa, predromantizam

Na samom početku šesnaestog veka, mletački Split je - poput starozavetne Vetulije - bio pod opsadom vojnički superiornog i ,bezbožnog“ neprijatelja s Istoka, a Marko Marulić (1450-1524) se upravo u tom sumornom istorijskom trenutku upustio u stvaralački poduhvat, koji ga je pre tačno pet vekova uveo u red

*rasha@ff.uns.ac.rs, nevena@ff.uns.ac.rs 
besmrtnih bardova evropskog pesništva. ${ }^{1}$ Kao što je već u stručnoj literaturi istaknuto: "[Marko Marulić] bio je od onih pisaca koji su plodu svoga spisateljskog rada namenjivali važnu ulogu, koji su studiozno odabirali sadržinu (imajući, često, u vidu i mogućnost njenog alegorijskog značenja) i formu koja će tu sadržinu na odgovarajući način da predstavi (Bojović, 1989: 34). Stoga ćemo i mi, poput pisca koji je to sugestivno naznačio u svojoj posveti kumu Dujmu Balistriliću, pokušati da razjasnimo ulogu starozavetnog predloška u pesničkom oblikovanju slavnog podviga udovice iz Vetulije. ${ }^{2}$ Deuterokanonska Knjiga o Juditi bila je dobro poznata šesnaestovekovnim čitaocima Marulićevog epa, jer je prevodilački rad njegovog dalmatinskog zemljaka - Svetog Jeronima Stridonskog - podstakao već krajem četvrtog veka nove ere veliko (liturgijsko, likovno i literarno) interesovanje za takozvani aleksandrijski korpus starozavetnih tekstova. Biblijska pripovest o Juditi sadrži šesnaest poglavlja, dok je Marulić svoj ep kompozicijski organizovao u šest poglavlja, koja imaju ukupno preko dve hiljade stihova. U deuterokanonskom tekstu glavna junakinja pojavljuje se tek u 8. poglavlju, prikazana je nedvosmisleno kao ličnost koja ne pripada socijalnoj margini vetulijske zajednice, iako je žena i udovica. Pored toga, ona je svesna dramatičnih događaja koji se tada odvijaju na granicama Judeje: „U one dane ove riječi čula je i udovica Judita“ (Biblija, 2007: 474). Njenim pojavljivanjem stvorena je protivteža u kompoziciji biblijskog teksta, jer njena tiha uzdržanost predstavlja snažan kontrast kolektivnom kriku zastrašene zajednice, odnosno vapaju koji narod Betulije upućuje Jehovi. ${ }^{3}$ Judita je mudra i skromna - ona je i ćerka i sugrađanka i udovica - ali je takođe i statusno ravnopravna sa poglavarima koji se savetuju s njom. Ona ne spominje slučajno u svojim besedama Avrama i Jakova, čime su nam starozavetni redaktori sugerisali da je mudra udovica osoba koja dobro poznaje Toru (uprkos tome, Judita je prevashodno ikonografski simbol pobožnosti i skromnosti, zato što ni u jednom trenutku ne ističe svoju ulogu, već samo najavljuje spasonosnu intervenciju Boga protiv nevernika). Upravo u tome možemo zapaziti središnju religiozno-didaktičku poruku priče o Juditinom herojskom činu: njenom rukom, Bog će doneti spas, bez obzira na to što je ona samo žena, suočena s moćnim asirskim generalom. Judita ne

\footnotetext{
${ }^{1}$ Kako je „Judita“ Marka Marulića štampana 1521, ove godine navršava se upravo petstota godišnjica prvog izdanja. (op. a.)

${ }^{2}$ Za potrebe uvodnog segmenta koautorskog rada, koristili smo Bibliju u izdanju Hrvatskog biblijskog društva iz Zagreba (Biblija, 2007). (op. a.)

${ }^{3}$ Naziv grada Betulija ili Vetulija etimološki upućuje na hebrejsku imenicu „betula“ koja označava devicu, neudatu žensku osobu. (op. a.)
} 
računa na svoju, već na božansku snagu, zato što samo Jehova može da trijumfuje nad Nabukodonosorom, asirskim carem i lažnim božanstvom. Kada su u pitanju intertekstualne relacije između predloška i religioznih epova Marulića i Kovačevića, u starozavetnom tekstu i analiziranim pesničkim tvorevinama podjednako se insistira na tome da Judita zadivljuje ne samo svojom mudrošću, nego i fizičkom lepotom, koja je i doslovno obezglavila Holoferna. ${ }^{4}$ Posmatrano iz šire hermeneutičke perspektive, uzvišena ženska figura u Bibliji veoma često simbolizuje ceo narod, a pripovest o Juditinom poduhvatu ne bi trebalo tumačiti kao Marulićevu stihovanu filipiku uperenu protiv Osmanlija, nego kao odraz pesnikovog ubeđenja da samo vera u Gospoda određuje ishod sukoba između Neba i Podzemlja.

Judita je grandiozni biblijski lik poput Davida, zato što preuzima na sebe veliku odgovornost, izlažući se bez oklevanja smrtnoj opasnosti. Imajući u vidu simboliku ove biblijske priče, koja je svakako bila veoma bliska renesansnim književnicima i filozofima, mi - čitaoci dvadeset i prvog veka, držeći u jednoj ruci biblijski tekst, a u drugoj Marulićevo pesničko delo - možemo da „oslušnemo“ svevremene po(r)uke koje sadrži tematska struktura navedenih tekstova, razdvojenih hronološkom distancom od nekoliko hiljada godina. U savremenom istraživačkom pristupu Marulićevom epu, po pravilu se nameću tri ključna pitanja: zašto ga Marko Marulić Splićanin piše, kako ga je spevao i kada? Ta pitanja zapravo i jesu ključ za modernu reinterpretaciju renesansnog dela, nastalog pre tačno pet vekova (1521). Već samim naslovom „Libar Marka Marula Splićanina u kom se uzdrži istorija svete udovice Judit u versih hrvacki složena kako ona ubi vojvodu Oloferna po sridu vojske njegove i oslobodi puk izraelski od velike pogibli“" (Marulić, 1983: 4) ${ }^{5}$ uz kratak siže, pisac žanrovski određuje svoje delo ${ }^{6}-$

\footnotetext{
${ }^{4}$ Ubistvo Holoferna često je prikazivano u renesansnom i baroknom slikarstvu, a inspirisalo je i slikare kasnijih epoha. Tema Judite i Holoferna, takođe se pojavljuje i u muzičkim oratorijumima Antonija Vivaldija i Volfanga Amadeusa Mocarta, a 2008. godine francuski kompozitor Filip Fenelon napisao je operu „Judita“. Pored toga, dva filma snimljena su o Juditi tokom 20. veka: francuski nemi film „Judita i Holoferno“ (1909) i hrvatski televizijski film, prema epu Marka Marulića (1980). (op. a.)

5 Fotografija originalne naslovne strane Marulićevog dela dostupna je na sledećoj elektronskoj adresi: https://www.alamy.com/789-illustrated-page-from-the-second-editionof-judita-by-marko-maruli-1522-image213690986.html (op. a.)
} 
poput biblijske Knjige o Juditi i ovo su knjige „u šest libri razdiljena“ (Marulić, 1983: 16) i navodi kojim jezikom piše, te da će delo biti u stihu. Već pri prvom hermeneutičkom susretu $\mathrm{s}$ delom, lako zapažamo da pisac ništa nije prepustio slučajnosti. Osobenim jezikom, biranim stilskim postupcima, savršeno organizovanim dvostruko rimovanim dvanaestercima $u$ kojima se rima sastoji mahom od glagolskih oblika, Marulić stvara epsko delo koje će biti ne samo čitano, nego i homerski javno pevano. Njegov rodni grad krajem 15.veka imao je oko 5.000 stanovnika i možemo da zamislimo njegove (ne)pismene splitske sugrađane kako slušaju (sic!) stihove iz Marulićevog dela. Svestan je Marulić, prepoznajemo to iz posvete, da nisu svi vični jezicima kojima je sam vladao i zato piše na narodnom jeziku: „Tuj historiju čtući, ulize mi u pamet, da ju stumačim našim jazikom, neka ju budu razumiti i oni ki nisu naučni knjige latinske aliti djačke“" (Marulić, 1983: 6). Dalje, svako ko je iole tada poznavao povest o Juditi, mogao je da uvidi sličnost sa aktuelnom političkom situacijom, a na pojedinim mestima pesnik je nedvosmisleno aludirao na Turke: „Drugo libro. Kuda Olofernes projde s vojskom; kih poda se podbi; pride u Gabu; bi strah u Jerosolim; pozlobiše Akiora veziri (naš kurziv, op. a.), jer istinu govori od naroda jerosolimskoga" (Marulić, 1983: 14). Kompleksnost pesničke ličnosti Marka Marulića uviđamo i kada ga posmatramo kao reprezentativnog predstavnika južnoslovenske književne tradicije. Poput Dubrovčanina Mavra Vetranovića, i on je ukazavao na hrišćanske vrline, ali i grehe pogubne za ljudsku dušu. To su, pre svih, pohlepa/skupost i gordost, koje ostaju nezasite sve do smrti grešnika. Već u prvom pevanju pisac iskazuje uverenje da je volja nasilja uvek naspram božje volje, a onda, poput svoji antičkih pesničkih uzora, kataloški prikazuje asirsku vojsku, konje i oružje, a slike završava portretom glavnog zapovednika: „[a on ti] sijaše oholo, visoko,/ a sam pogledaše po vojsku široko;/krvavo mu oko, črljen biše obraz,/brada jur nikoko prosida, debel haz" (Marulić, 1983: 28). Marulićeve pesničke slike vrlo su plastične i dočaravaju junake, rekli bismo, u njihovoj sadašnjosti i budućnosti. Naime, čitajući navedeni opis u ova četiri stiha, čitaoci mogu Oloferna lako da zamisle na kraju, opruženog nakon pijanstva, sa debelim trbuhom, krvavog i mrtvog. Marulić se pažljivo pozabavio svim aspektima svog dela: ,pitanjima forme [Marulić] se bavio savesno, i to forme u najširem smislu, od kompozicije dela i organizovanja pesničke materije do jezičke izražajnosti i slikovitosti““(Bojović, 1989: 38), a postoje pretpostavke da

${ }^{6}$ Sama reč koju autor upotrebljava znači ,knjiga/knjige“, dok potonji proučavaoci delo različito određuju i kao „epska pesma“ (Marulić, 1901) ili kao spev (Franičević, 1983: 230). (op. a.) 
je za drugo izdanje epa, koje je štampano već 1522. godine, sam izradio duboreze. ${ }^{7}$ U drugom pevanju, predstavljajući ,asirsku“ osvajačku silu, nizao je stihove o prolaznosti života koji su, pokazuje se, tematski veoma bliski ne samo njegovim savremenicima, nego i Ivanu Dživu Gunduliću (1589-1638), baroknom autoru koji je živeo i stvarao stotinu godina kasnije: „I koji je sad željan da vlada zemljom svom,/Malo, malo počekavši, hrana će biti crvima./Onaj koji sad svakim zlom pritišće narod ovaj/Bit će poslije pritisnut kamenim pokrivačem“ (Marulić, 1983: 39). Zajednička tematska nit koja spaja hrišćansku renesansu i baroknu religioznu misao jeste verovanje u milost božiju, odnosno uverenje da je ona iznad svakog greha. Poput molitve zvuče mudri saveti Marulićevog Elijakimova: „Velim vam ja da će Bog imati smilovanja uslišavši vas/Postove i molitve samo ne zanemarite,/ Djelo poniznosti svaki dan prikažite“ (Marulić, 1983: 45). Pre nego što će se pojaviti glavna junakinja, u epu se, kao prvi antipod neprijateljskoj sili pojavljuje Ahior, koga uz poniznost odlikuje i istinoljubivost. Njegova uloga je višestruka, on je glas razuma koji upozorava na pogubnost oholosti i hvalisavosti, ali ga možemo posmatrati i kao nekoga ko najavljuje Juditin dolazak, što je funkcija koja je dodeljena i istoimenom akteru religioznog epa Gavrila Kovačevića (Kovačević, 1808). Jer, poput biblijske knjige u kojoj se udovica pojavljuje na sredini pripovedačkog toka, u osmom poglavlju, tako se i u Marulićevom epu pojavljuje u (središnjem) trećem libru. Sve u vezi sa njom dato je u superlativu: „Tada se nalažaše u tome gradu Judita,/ Koja sve nadmaši ljepotom, dobrotom,/ Koja odluči život živjeti prečisto/ Otkako postade udovica“" (Marulić, 1983: 65), a svojim sugrađanima obraća se molbom da budu ponizni. U stihovima u kojima progovara Judita, govoreći o grehu i milosti, Marulić je poetski prethodnik još jednom piscu iz 17. veka, Peraštaninu Andriji Zmajeviću. U stihovima: „Govoreći: karanje Božje manje je/ Od našega sagrešenja i naše poganštine“ (Marulić, 1983: 69) prepoznajemo verovanje $\mathrm{u}$ ispravnost (transcedentnog) božjeg dejstva na živote grešnika. Ahior i Judita, kazujući istinu svom narodu, obraćaju se, zapravo, građanima Splita Marulićevog doba (smatramo da se u trećem pevanju Marulić najdirektnije obratio mnogogrešnim sugrađanima).

Naredno pevanje obeleženo je Juditinom odlukom da ode Holofernu, a zatim i scenom njenog ulepšavanja: ,Zaslijepi ga, neka ga dodirne/ Mreža moje ljepote i zamka očiju./ Kad s njim prozborim, da se riječi jezika/ Moga zabiju u srce

\footnotetext{
${ }^{7}$ Pomenute duborezne ilustracije za Marulićevo pesničko delo dostupne su na sledećoj elektronskoj adresi: https://www.google.com/search?q=marko+maruli\%C4\%87+judita+slik e\&rlz=1C1GCEA enRS935RS935\&sxsrf=ALeKk03Y2YTcorC- (op. a.)
} 
toga čovjeka“ (Marulić, 1983: 75). Uočava se, pre svega, svest koju ona poseduje o moći svoje lepote, o varljivosti očiju i magiji reči, ali i mudrost zahvaljujući kojoj zna kako da se (sa)vlada. Iako pesnički sastav i fikcija ne mogu imati dokumentarnu vrednost, opisi njenog ulepšavanja i uređivanja za Holoferna, mogu se interpretirati i kao svedočanstvo o šesnaestovekovnim modnim trendovima, na prostoru Mletačke republike. I Juditu, zahvaljujući pikturalnosti Marka Marulića, možemo da zamislimo kao zavodljivu figuru sa slike nekog od čuvenih renesansnih ili baroknih slikarskih majstora. I zaista, kako bi Asirski vojskovođa odoleo nekome za koga stihotvorac kaže: „Bila bi dostojna s knezovima na sagu sjediti;/ I čak ići na pir s kraljicama/ I biti štovana među banicama“ (Marulić, 1983: 77). Iako bi, možda, bilo očekivano da ovako prikazanu biblijsku junakinju, njen pesnički apologeta poredi sa drugim starozavetnim i novozavetnim ličnostima, daroviti splitski polihistor niže poređenja sa antičkim mitološkim figurama - sa Dijanom, lepom Jelenom i mnogim drugim heroinama. Ali, za razliku od njih, Judita je, pre svega, žena čiju svakodnevicu obeležavaju molitva, poniznost i vera u Svetlost. Insistirajući na tome, Marulić, zaključujemo, čitaoca priprema za njen ubilački čin, koji je apriorno označen kao moralan, častan i ispravan. Glavna junakinja ostaje čista $i$ istrajna u svojoj nameri da pomogne svom narodu. Nadasve vešto prikazana je Judita u trenutku Holofernovog ubistva. Marulićeva pobožna junakinja nije hladnokrvna poput Agamemnonove osvetoljubive Klitemnestre. Ona se prvo obraća Bogu za dozvolu i snagu, jer njen ubilački čin podjednako simbolizuje greh i spasenje. Stihovi kojima se opisuje Holofernovo obezglavljivanje kao da su u saglasnosti sa slikarskim predstavama, na koje smo već nekoliko puta podsetili potencijalne čitaoce našeg koautorskog istraživačkog rada: „Hronu, strepi sobom, ležeći on uznak,/drhta ruka s nogom, vas se oslabi, pak/ izdaše; ne bi jak; grkljanom siča krv: / tako t' zgibe junak, tako spusti obrv./ Zgrize ga malo črv oružjem njegovim,/ ubi ga ženska srv, ki biše prosto dim/ da zajme svitom svim; ki mnjaše da ni Bog/ silam njegovim tim jest protiviti mog“" (Marulić, 1983: 102). Kada bi postojalo specijalno čarobno ogledalo - zamislimo ga kao oneobičeni artefakt blizak čitaocima proze Luisa Kerola i Milorada Pavića - koje bismo postavili između trećeg i četvrtog libra Marulićevog epa, primetili bismo da se poglavlja ogledaju (prvo i šesto, drugo i peto, treće i četvrto, te da u takvoj kontrastnoj simetriji zapravo čine savršenu celinu, sastavljenu od harmonično ustrojenih narativnih krugova). U prvom je opisana silna asirska vojska, a u šestom libru prikazan oslobođen betulijski narod; u drugom pevanju Ahior apeluje na razum, dok je u petom zapovednik posečen; u trećoj knjizi prikazan je izraelski narod, sva zlodela neprijatelja i pitanja da li će Betuljani posustati, dok je četvrtom uvedena 
nova drama, predstavljena je Juditina lepota i nada u pobedu. Marko Marulić je u prelomnom trenutku lične i kolektivne istorije, sastavio poetski venac u kojem je suprotstavio motive Dobra i Zla, a samim tim i njihovu neprekidnu borbu, koja predstavlja svojevrsnu ontološku konstantu u duši i umu svakog potencijalnog čitaoca njegovog pesničkog dela.

Kao što smo već nagovestili na početku ovog teksta, druga problemska celina u okviru našeg istraživanja posvećena je intertekstualnim vezama između Knjige o Juditi i predromantičarskog sočinenija Gavrila Kovačevića (1765-1832), koje je postalo predmet kompetentnih književnoistorijskih tumačenja tek krajem 20. i početkom 21. veka (Damjanov, 1988; Pavić, 1991; Eraković, 2007; Eraković, 2008). ${ }^{8}$ Pre nego što pređemo na analizu dëla Judit mečem Olofernu glavu useknuvši tem Judeju osvobodivši (Kovačević, 1808), želimo da istaknemo kako su nas viševekovne teološke rasprave, o bogoslužbenom statusu deuterokanonskih pripovesti, podstakle na dodatan hermeneutički oprez prilikom rekonstruisanja horizonta očekivanja srpske osamnaestovekovne i devetnaestovekovne čitalačke publike. $^{9} \quad$ Naime, višegodišnje proučavanje epskog pesništva srpskog predromantizma, omogućilo nam je da identifikujemo kauzalnu povezanost recepcijskog potencijala biblijskih predložaka i kulturološkim kontekstom oblikovanih „metakoncepata“ (Wolf, 2006: 4-6), karakterističnih upravo za epohu kojoj su pripadali srpski predromantičari. Pored toga, dijahronijska analiza

${ }^{8}$ Gavrilo Kovačević je početkom 19. veka stekao reputaciju talentovanog sočinitelja, zahvaljujući pesničkom ostvarenju u kojem je apologetski opisan podvig „Lazara Grebljanoviča sina Priba Grebljanoviča“" (Kovačević, 1805: 4). Prvo izdanje dela Stihi o povedeniji, i namereniji serbskago velikago knjaza Lazarja protiv turskago opolčenija, s raznimi jego velmožej razgovori: $i$ o izobraženiji strašnago, i groznago onago meždu Serbami i Turkami, na polju Kosovu sraženija, slučivšagosja vo 1389-m lete, junija 15-go dne objavljeno je u Budimu 1805. godine. Uprkos nespornoj književnoistorijskoj i poetičkoj relevantnosti Kovačevićevog epa o Juditi (Kovačević, 1808), nijedno drugo delo zemunskog pesnika nije steklo tako veliku naklonost srpskih devetnaestovekovnih čitalaca kao njegov istorijski spev o Kosovskoj bici (sačuvani su bibliografski podaci o čak sedam izdanja ovog dela, objavljenih u periodu između 1805. i 1857. godine). (op. a.)

${ }^{9}$ Moramo naglasiti da smo već u preliminarnoj fazi našeg istraživanja uzeli u obzir ne samo bibliografski, nego i kulturološki značaj podatka da je - zahvaljujući izdavačkom poduhvatu mitropolita Stefana Stratimirovića (1757-1836) - prvoj generaciji čitalaca Kovačevićevog religioznog epa (Kovačević 1808) bilo dostupno izdanje Slovenske Biblije na ruskocrkvenoslovenskom jeziku, koje sadrži i Knjigu o Juditi ([Stratimirović], 1804). (op. a.) 
tematsko-motivske strukture srpskog osamnaestovekovnog građanskog pesništva, omogućila nam je da izdvojimo nekoliko crnohumornih osvrta na Holofernovu sudbinu (Marinković, 1966a: 429; 503-504; 511), što potvrđuje ispravnost teorijske pretpostavke o sposobnosti teksta da sačuva pamćenje na prethodne kontekste (Lotman, 2004: 26). Međutim, u srpskim građanskim pesmaricama je lik udovice iz Vetulije preobražen u lukavu plautovsku heteru, koja s lakoćom zavodi starozavetnu preteču hvalisavog Pirgopolinika. Usled toga je opravdano zaključiti da je izvorna biblijska pripovest, o Juditinom slavnom podvigu, odigrala mnogo važniju ulogu u nastanku poetsko-epskog ostvarenja Gavrila Kovačevića, nego srpsko osamnaestovekovno građansko pesništvo.

$\mathrm{S}$ obzirom na to da smo u prethodnom segmentu rada identifikovali popularnu starozavetnu priču kao glavni predložak Kovačevićevog epa, sasvim je razumljivo zbog čega je prolog ovog dëla tematski zasnovan na autorovom tumačenju (pseudo)istorijskih okolnosti, koje su izazvale vojnu intervenciju Asirije protiv jevrejskog naroda (Kovačević, 2018: 29). ${ }^{10} \mathrm{Na}$ samom početku analiziranog epa, čitalac saznaje da je asirska vojska krenula u kazneni pohod protiv pobunjenika koji su se udružili s carevim neprijateljima (Kovačević, 2018: 30). Prema sugestivnoj interpretaciji srpskog predromantičara, sudbina svih onih podanika koji su otkazali poslušnost Nabukodonosoru, bila je zapečaćena čim je gnevni vladar saznao za verolomstvo svojih vazala. Slično Marku Maruliću, srpski predromantičar se opredelio za linearni model prilikom hronološko-gradativnog predstavljanja dramatičnih događaja, koji čitaoca postupno dovode do opsade Vetulije kao kulminacijske tačke u kompoziciji dela. Stoga je drugo poglavlje Kovačevićevog epa tematski zasnovano na detaljnom opisu apokaliptične sudbine mesopotamijskih i arabijskih gradova koje je zauzeo general Holofern, odnosno „vojenačalnik Olofern“ (Kovačević, 2018: 32).

Uprkos tome što opisi ratnih razaranja preovladavaju i u drugom poglavlju epa, navedena tematska celina značajna je za našu analizu prvenstveno zbog kratke

\footnotetext{
${ }^{10}$ Posmatrano iz savremene kulturološke perspektive, tematska struktura Knjige o Juditi potvrđuje ispravnost moderne teorijske pretpostavke o uticaju drevnih mitova na stvaranje i oblikovanje nacionalno-imagotipskih sistema (Fischer, 2009: 43). Naime, pseudofaktografsko spajanje istorija dva carstva (Nabukodonosor je bio vavilonski, a ne asirski vladar, a upravo je Vavilon uništio asirsko carstvo krajem sedmog veka pre nove ere) opravdalo je upotrebu tolkinovski maštovitog pripovedačkog postupka, zasnovanog na hiperbolizaciji vojne moći stranaca-pagana, koje je sramotno porazio malobrojni ali pobožni Izabrani narod (sic!). (op. a.)
} 
dijaloške scene, koja dodatno afirmiše pretpostavku o ranoromantičarskom modelu demonizacije glavnog muškog lika u Kovačevićevom delu (Eraković 2008: 179180). Naime, nemilosrdni vojskovođa je poručio pokorenim narodima da će im životi biti pošteđeni, pod uslovom da priznaju asirskog vladara za vrhovno božanstvo (Kovačević, 2018: 33). Ako uzmemo u obzir činjenicu da je u prologu eksplicitno navedeno kako je kazneni pohod bio pokrenut iz političkih i finansijskih razloga, onda možemo zaključiti da nametanje paganskog kulta predstavlja svojevrsnu naratološko-kognitivnu disonancu, zbog toga što blasfemični karakter asirske represije nije usklađen s piščevim ekspozicijskim tumačenjem uzroka carske odmazde. Na osnovu toga što energični sledbenik asirskog demijurga posvećuje veliku pažnju sprovođenju carske naredbe, već od trećeg poglavlja postaje jasno da Judit mečem Olofernu glavu useknuvši tem Judeju osvobodivši sadrži niz tematskih odstupanja, u odnosu na deuterokanonski zapis o suočavanju pobožne udovice s paganskim ratnikom. Potraga za uzrocima mefistofelovskog preobražaja glavnog muškog lika u delu zemunskog sočinitelja, dovela nas je do zaključka kako u judejskom (kolektivnom) odbacivanju faustovske pogodbe ne možemo zapaziti tragove fanatičnog samopouzdanja, zasnovanog na uverenju da će Bog (ipak) zaštiti Izabrani narod od uništenja (Kovačević, 2018: 34-35). Umesto toga, epizodne likove poput stanovnika Jerusalima obuzima atavistički strah od smrti, a malodušni gubitak nade u božansku intervenciju dovodi do paničnog bekstva naroda u planine. U ponašanju žitelja judejskih naseobina nema ni traga od ratničkog entuzijazma koji je obuzeo asirske vojnike (Kovačević, 2018: 35), tako da piščevo inventivno oblikovanje prizora neizvesne borbe između Neba i Podzemlja, potvrđuje tačnost pretpostavke o književnoistorijskoj relevantnosti dela Judit mečem Olofernu glavu useknuvši tem Judeju osvobodivši .

Nažalost, bez obzira na to što se iskusni slavenosrpski pesnik u petom poglavlju opredelio za jednu od osnovnih pripovedačkih tehnika epskog peništva, nedovoljno vešta upotreba retardacije nije dala rezultat koji bio opravdao konstataciju o ujednačenoj umetničkoj vrednosti svih tematskih celina Kovačevićevog religioznog epa. Umesto miltonovski raskošnih opisa ratničkih priprema za konačni obračun Dobra i Zla, autor je u ovom poglavlju dao prednost retrospektivnom osvrtu na istoriju jevrejskog naroda, tako da su Asirci dobili od dramatizovanog pripovedača bedekerski precizne informacije o religiji i običajima pobunjenika, skrivenih u hananskim planinama (Kovačević, 2018: 36-37). S obzirom na činjenicu da smo $u$ našim prethodno publikovanim tumačenjima Kovačevićevog sočinenija objasnili zbog čega je upravo liku Ahiora Amonitskog dodeljena funkcija homodijegetičkog pripovedača (Eraković, 2007: 119-130; 
Eraković, 2008: 172-173), postupak uporedne analize Marulićevog i Kovačevićevog epa obavezuje nas da posvetimo dodatnu istraživačku pažnju reakciji asirskog generala na Ahiorovu profetsku besedu. Kako bismo opravdali našu inicijalnu pretpostavku o ranoromantičarskoj demonizaciji bezbožnog oponenta Više sile u Kovačevićevom delu, izdvojićemo Olofernovu naredbu da amonitski Tiresija bude okovan i bačen pod zidine opsednutog judejskog grada, kako bi iskusio sudbinu izmučenih branilaca Vetulije (Kovačević, 2018: 38). Našu tezu o dijaboličkoj karakterizaciji lika asirskog vojkovođe potvrđuje ne samo udes istinoljubivog rapsoda, nego i Olofernovov teomahijski hibris, zbog kojeg Kovačevićev negativni junak zaslužuje da bude upoređen s Njegoševim „zlim gubiteljem duša bezsmtnijeh" (Petrović Njegoš, 1845: 47).

Kao što smo već nekoliko puta istakli u ovom radu, recepcijski izuzetno privlačna biblijska pripovest o asasinskom poduhvatu judejske lepotice inspirisala je najdarovitije renesansne i barokne slikare, poput Andreja Mantenje (1431-1506), Lukasa Kranaha Starijeg (1472-1553), Mikelanđela Karavađa (1571-1610) i, naravno, Artemizije Đentileski (1593-1656?). Međutim, ako bismo bili primorani da izdvojimo ime samo jednog umetnika, čije je likovno delo najviše usklađeno s našim intimnim čitalačkim impresijama o liku Kovačevićeve Judite, onda bismo se bez svake sumnje opredelili za erotizmom prožeto ostvarenje Gustava Klimta (1862-1918). Na primer, poetički i estetski značaj scene prvog susreta Oloferna i Judite ne ogleda se u neinventivnom starozavetnom isticanju sile koju poseduje paganski vojskovođa, već u klimtovskom sjaju zlatnih predmeta, kojima je judejska lepotica okružena u Olofernovom vladarski raskošnom šatoru (Kovačević, 2018: 49). Uprkos tome što je Judita uspela da uđe u asirski logor zahvaljujući (ne)uverljivom objašnjenju da je nepogrešiva proročica, opčinjenost asirskih stražara njenom erotičnom pojavom sugestivno je predstavljena kao pravi razlog zbog čega je misteriozna gošća odmah odvedena Olofernu (Kovačević, 2018: 48). Profetske usluge zanosne udovice nisu bile potrebne carevom najboljem zapovedniku, čvrsto uverenom u laku pobedu nad vojnički inferiornim neprijateljem, a prezrivo odbacivanje Ahiorovih upozorenja dodatno opravdava pretpostavku da Asirci nisu bili impresionirani Juditinim hibridnim identitetom, već njenom „krasotom“ (Kovačević, 2018: 49).

Nakon vešto isplaniranog stupanja na glavnu pozornicu, lik vetulijske Kasandre zadržava dominantnu poziciju u delu sve do epiloga religioznog epa Gavrila Kovačevića. Pažnja koju je srpski autor posvetio stvaranju rusoovski idealizovane slike prirode, odnosno pastoralnog prostora u kojem se Judita svake noći moli Bogu (Kovačević, 2018: 53), trebalo bi protumačiti kao još jedan dokaz o 
pesnikovom predromantičarskom senzibiltetu. Moramo takođe naglasiti da su pomenute narativne repeticije dobile, u sižejnoj strukturi Kovačevićevog epa, mnogo pragmatičniju funkciju od one koja im je dodeljena u izvornoj starozavetnoj pripovesti. Naime, Juditini nokturnalni izleti su veoma brzo prestali da privlače pažnju stražara, tako da je obezglavljeno generalovo telo pronađeno tek nakon što je vetulijska femme fatale napustila asirski logor (Kovačević, 2018: 57). Olofernovo ubistvo sasvim opravdano možemo označiti kao kulminacijsku tačku ne samo deuterokanonskog predloška, nego i pesničkih ostvarenja Marka Marulića i Gavrila Kovačevića. Ipak, pažljivija analiza tematske strukture završnog segmenta Kovačevićevog epa (Kovačević, 2018: 58-64), uz poseban osvrt na opis ceremonijalne proslave Juditinog podviga u Vetuliji, dovela nas je do zaključka da epilogu religioznog epa Gavrila Kovačevića, nažalost, nedostaje originalni stvaralački pečat u poetskoj interpretaciji događaja, koji su se odigrali nakon paničnog bekstva obezglavljene (sic!) asirske vojske (Kovačević, 2018: 61).

Da zaključimo, rezultati našeg komparativnog istraživačkog rada potvrdili su tačnost pretpostavke o književnoistorijskoj relevantnosti epa Judit mečem Olofernu glavu useknuvši tem Judeju osvobodivši. Međutim, dominantni status religiozno-didaktičke komponente $u$ tematskoj strukturi analiziranog dela je, prema našem mišljenju, redukovao umetničku vrednost jedinog srpskog predromantičarskog epa inspirisanog Knjigom o Juditi. Za razliku od Marka Marulića, čije delo nesumnjivo pripada vrednosnom vrhu evropskog i južnoslovenskog religioznog pesništva, preobražaj biblijskih prototipova $u$ književne junake je očigledno predstavljao (pre)veliki stvaralački izazov za srpskog predromantičara. S jedne strane, Gavrilo Kovačević je nesumnjivo uložio veliki stvaralački trud kako bi starozavetnu pripovest o Juditi transformisao u autentičnu poetsku viziju kosmogonijskog sukoba Svetlosti i Tame. S druge strane, naše dugogodišnje istraživačko i hermeneutičko iskustvo nam omogućava da konstatujemo kako je u pitanju pesnički izazov s kojim su se uspešno izborili samo najdarovitiji evropski i južnoslovenski bardovi, poput Marka Marulića (14501524), Džona Miltona (1608-1674) i Petra Drugog Petrovića Njegoša (1813-1851). Ipak, bez obzira na naše negativno vrednovanje određenih kompozicijskih i tematskih nedostataka epa Judit mečem Olofernu glavu useknuvši tem Judeju osvobodivši, stvaralaštvu Gavrila Kovačevića pripada istaknuto mesto, u okviru savremenih komparativnih proučavanja južnoslovenskih književnosti. 
Radoslav Eraković, Nevena Varnica

BEAUTY, SWORD AND PRAYER: OLD-TESTAMENT WIDOW FROM BETHULIA PORTRAYED IN WORKS OF MARKO MARULIĆ AND GAVRILO KOVAČEVIĆ

\section{Summary}

This study presents results of a comparative analysis of two religious epics authored by Marko Marulić (1450-1524) and Gavrilo Kovačević (1765-1832) respectively. Their respective works are somewhat equally inspired by the Biblical story of Judith, the widow from Bethulia (Marulić 1521; Kovačević 1808). Looking from the contemporary literaryhistorical and cultural point of view, the manner in which the Old Testament story was remodelled in the works of the two South Slavic poets confirms the veracity of the modern theoretical presumption about the impact of ancient myths onto the creation of nationalimagotypical systems (Fischer, 2009). More precisely, pseudo-factographic "merging" of key events from the history of various Near East empires (Babylon, Assyria and even Ottoman Empire) justified for exaggerating about the magnanimity of the military power of infidels, who were triumphantly won over by a small in number, but pious people. In the initial phase of this research special attention was paid to the interpretation of intertextual relations between the deuterocanonical story and religious epics of the two authors whose works have not been ever, up to now, studied through comparative analysis. This comparative approach to the subject of the research provided more precise identification of common touching elements between respective poetical works of Marko Marulić and Gavrilo Kovačević (genre-wise, poetics-wise and topic-wise).

Keywords: Marko Marulić, Gavrilo Kovačević, Book of Judith, religious epics, SouthSlavic literatures, Renaissance, Pre-romanticism.

\section{LITERATURA}

Biblija, (2007). Biblija : Sveto pismo staroga i novoga zavjeta. Zagreb : Hrvatsko biblijsko društvo.

Bojović, Z. (1989). Marulićeve posvete. U: Dani hvarskog kazališta. Hrvatska akademija znanosti i umjetnosti i Književni krug Split: Split, 34-46.

Damjanov, S. (1988). Koreni moderne srpske fantastike: fantastika u književnosti srpskog predromantizma. Novi Sad: Matica srpska. (штампано ћирилицом)

Eraković, R. (2007). Elementi starozavetne tradicije kao tematska ishodišta religioznih epova srpskog predromantizma. U: Karanović, Z; GikićPetrović, R. (ur.) Sinhronijsko i dijahronijsko izučavanje vrsta u srpskoj književnosti. Knj. 1. Novi Sad: Filozofski fakultet, 119-130. (штампано ћирилицом) 
Eraković, R. (2008). Religiozni ep srpskog predromantizma. Novi Sad: Matica srpska.(штампано ћирилицом)

Fischer, Manfred S. (2009). „Komparatistička imagologija: za interdisciplinarno istraživanje nacionalno-imagotipskih sustava“. U: Dukić, D., Blažević Z., Plejić P., \& Brković, I. (prir.) (2009). Kako vidimo strane zemlje: Uvod u imagologiju. Zagreb: Srednja Europa. 37-57.

Franičević, M. (1983). Povijest hrvatske renesansne književnosti. Zagreb: Školska knjiga.

Kovačević, G. (1805). Stihi o povedeniji, i namereniji serbskago velikago knjaza Lazarja protiv turskago opolčenija, s raznimi jego velmožej razgovori: i o izobraženiji strašnago, i groznago onago meždu Serbami i Turkami, na polju Kosovu sraženija, slučivšagosja vo 1389-m letu, junija 15-go dne. Budim: Slaveno-srbska pečatnja Kraljevskago vseučilišta vengerskago. (штампано ћирилицом)

Kovačević, G. (1808). Judit mečem Olofernu glavu useknuvši tem Judeju osvobodivši. Budim: Slaveno-srbska pečatnja Kraljevskago vseučilišta vengerskago. (штампано ћирилицом)

Kovačević, G. (2018). Judit mečem Olofernu glavu useknuvši tem Judeju osvobodivši [prir. Damjanov, S; Eraković, R]. Novi Sad: Matica srpska. (штампано ћирилицом)

Lotman, J. (2004). Semiosfera: u svetu mišljenja: čovek, tekst, semiosfera, istorija. Novi Sad: Svetovi. (штампано ћирилицом)

Marinković, B. (1966). Srpska građanska poezija: XVIII i s početka XIX stoleća. Knj. 1-2. Beograd: Prosveta. (штампано ћирилицом)

Marulić, M. (1983). Judita (prev. i kom. Grčić, M). Zagreb: Mladost.

Pavić, M. (1991). Predromantizam. Beograd: Naučna knjiga. (штампано ћирилицом)

Petrović Njegoš, Petar. (1845). Luča mikrokozma. Beograd: Knjažestva srbskago knjigopečatnja. (штампано ћирилицом)

[Stratimirović, S.] (prir.) (1804). Biblija sirječ knigi svjaščenago pisanija Vethago $i$ Novago zaveta. Budim: Slaveno-srbska pečatnja Kraljevskago vseučilišta vengerskago. (штампано ћирилицом)

Wolf, W. "Introduction: Frames, Framings and Framing Borders in Literature and Other Media". In: Werner Wolf \& Walter Bernhart (eds.) (2006). Framing Borders in Literature and Other Media. Studies in Intermediality 1. Amsterdam: Rodopi, 2006. 1-40. 